\title{
DETERMINATION OF KINETIC PARAMETERS OF A LAB-SCALE UPFLOW ANAEROBIC SLUDGE BLANKET REATOR (UASB) REMOVING ORGANIC LOADING FROM SWINE MANURE EFFLUENTS
}

\author{
Determinação de parâmetros cinéticos utilizando reator anaeróbio de manta de lodo (UASB) em \\ escala laboratorial para remoção da carga orgânica de efluentes de suinocultura
}

\author{
Cláudio Milton Montenegro Campos ${ }^{1}$, Bruno Botelho Saléh ${ }^{2}$, Fernanda Ribeiro do Carmo ${ }^{3}$
}

\begin{abstract}
The present work aimed at determining and evaluating the kinetic parameters from the UASB reactor treating swine manure effluent in a lab-scale experiment. The research was carried out in the Laboratory of Water Analysis at the Engineering Department (LAADEG) at the campus of Federal University of Lavras - UFLA. The system was assembled with an acidification and equalization tank (AET), an UASB reactor and an aerated facultative pond (AFP). The hydraulic retention time (HRT) adopted in the UASB reactor were: $55 ; 39 ; 34 ; 24 ; 17$; and 16 hours. The operational average temperature in the UASB reactor was $25 \pm 2^{\circ} \mathrm{C}$. The kinetic studies used the following parameters: Chemical Oxygen Demand $\left(\mathrm{COD}_{\mathrm{T}}\right)$, Total Volatile Solids (TVS), Temperature, Flowrate and Total Solids Profile $\left(\mathrm{TVS}_{\mathrm{p}}\right.$ ), in the reactor, and the number of analyses were: $72 ; 72 ; 250 ; 250$; and 30, respectively. The frequency was twice a week for $\mathrm{COD}_{\mathrm{T}}$ and TVS, and daily for temperature and flowrate. The kinetic parameters determined were: yield coefficient $Y=0.3046$ to $0.4231 \mathrm{mg} \mathrm{COD}_{\mathrm{T}} \mathrm{mgTVS}^{-1}$. $\mathrm{d}^{-1}$, decay coefficient $K_{d}=0.0125$ to $0.0173 \mathrm{~d}^{-1}$, maximum growth rate coefficient $i_{\max }=0.2835$ to $0.03938 \mathrm{~d}^{-1}$ and limiting substrate concentration coefficient $K_{s}=51.70$ to $71.80 \mathrm{mg} \mathrm{COD} \cdot \mathrm{L}^{-1}$. The values found were within the range appointed in the specific literatures and were determined based on linear regression studies, giving in this way, a technical scientific support to the physical - chemical operational data collected during the operational research period.
\end{abstract}

Index terms: Swine effluents, UASB reactor, kinetic parameters.

\section{RESUMO}

Com a presente pesquisa, objetivou-se determinar os parâmetros cinéticos de um reator anaeróbio de manta de lodo (UASBUpflow Anaerobic Sludge Blanket), em escala laboratorial, empregado para reduzir a carga orgânica poluidora de dejetos de suínos. Os trabalhos foram conduzidos no Laboratório de Análise de Água do Departamento de Engenharia - LAADEG localizado no campus da UFLA, utilizando dejetos de suínos coletados da granja de suínos do Departamento de Zootecnia - DZO. O sistema de tratamento foi composto das seguintes unidades: tanque de acidificação e equalização (TAE), reator anaeróbio de manta de lodo (UASB) e lagoa aerada facultativa (LAF). Os tempos de detenção hidráulica (TDH) foram: 55; 39; 34; 24; 17; e 16 horas, adotados em função das cargas orgânicas biológicas e volumétricas. A temperatura média operacional no reator foi de $25 \pm 2^{\circ} \mathrm{C}$. O levantamento cinético utilizou os seguintes parâmetros: $\mathrm{DQO}_{\mathrm{T}}$, Sólidos Voláteis Totais (SVT), Temperatura, Vazão e Perfil de Lodo no reator (SVT), e o número de análises foram: 72; 72; 250; 250; e 30, respectivamente. As freqüências de análise foram duas vezes por semana para $\mathrm{DQO}_{\mathrm{T}} \mathrm{e}$ Sólidos Voláteis Totais (SVT), diárias para a Temperatura e Vazão. Foram determinados os seguintes parâmetros cinéticos: coeficiente de crescimento $Y=0,3046$ a $0,4231 \mathrm{mgDQO} \cdot \mathrm{mg} \mathrm{SVT}^{-1} \cdot \mathrm{d}^{-1}$, coeficiente de decaimento $K_{d}=0,0125$ a $0,0173 \mathrm{~d}^{-1}$, taxa máxima de crescimento $i_{\max }=0,2835$ a $0,03938 \mathrm{~d}^{-1}$ e concentração de substrato limitante $K_{s}=51,70$ a 71,80 mg. $\mathrm{L}^{-1}$ de DQO. Os valores encontrados estão dentro da faixa descrita em literaturas específicas e foram determinados com base em estudos de regressão linear, oferecendo assim, respaldo técnico científico aos dados físicos e químicos levantados durante a operacionalização do sistema.

Termos para indexação: Efluentes de suinocultura, reator UASB, parâmetros cinéticos.

(Recebido para publicação em 18 de janeiro de 2005 e aprovado em 10 de junho de 2005)

\section{INTRODUCTION}

Considering social and economical terms, the swine culture has an important contribution, mainly as an instrument of man fixation in the country areas, however, the residual pollution generated during the production process is enormous, and for this reason being considered by the environmental organs as one of the most pollutant activities which degrades the environment (CAMPOS et al., 1999).
Since the early 70's the swine management has been considered very dangerous in many aspects to the watershed, soil and atmosphere. In response to the increase of the demand, which intensified the production of confined animals, the pollution problems reached such dimension, that the Urban Development and Environmental Secretary of State pointed the swine culture, mainly the confined ones, as the most pollutant activity among all agroindustries.

\footnotetext{
${ }_{1}^{1}$ Professor Adjunto IV, Ph.D., Departamento de Engenharia da Universidade Federal de Lavras/UFLA - Cx. P. 3037 - 37.200-000 - Lavras, MG cmmcampos@ufla.br

Engnheira Agrícola, M.Sc., Departamento de Engenharia Agrícola, Universidade Federal de Lavras/UFLA - bbsaleh@fesurv.br

${ }^{3}$ Bolsista PIBIC-CNPq - Departamento de Engenharia/DEG - Universidade Federal de Lavras/UFLA -fnit_frc@ufla.br
} 
The development of the swine culture in Brazil, in the last years increased from 26.5 millions in 1993 to 37.7 million of heads in 2001 (ABIPECS, 2002). The manure volume can be estimated as a function of the herd and the managing practices. The utilization of anaerobic systems for treating the liquid effluents allow a more sustainable technology than other treatment processes, since the former is able to produce energy from the biogas and occupy less areas; and also the construction is quite simple and furthermore the sludge has more nutrients and micronutrients that can be disposed in the soil as fertilizers (NG \& CHIN, 1988; OLIVEIRA, 1993, 1997; ZHANG \& DAGUE, 1995).

The conventional anaerobic digesters normally used for treating manure residuals, has a very long hydraulic retention times (HRT); about 15 to 30 days. This long HRT is employed in order to allow the growth of microorganisms, and to avoid acidification and wash-out of them. With the increase of the scientific knowledge concerning the anaerobic process, it is quite possible to dissociate the HRT from the cellular retention time (CRT), therefore, the HRT is able to become just a few hours, while the CRT during many days (METCALF \& EDDY, 2003).

Among many reactors denominated "last generation reactors", one that can be stood out is the UASB (Upflow Anaerobic Sludge Blanket Reactor). This reactor is a result of a great development in treating simple and complex wastewaters, with high or low concentrations, soluble or with particulate material (KATO et al., 1999).

The UASB reactor does not use pack support materials, since the sludge which develops in its lower part has a concentrated biomass with a very high methanogenic activity, in the form of flocks or granules (pellets), which is called active zone (CAMPOS, 1998).

This type of sludge is generally attained through a selection process carried out through the ascended hydraulic flow (flowrate velocity through the reactor cross section), the type of substrate and also the volumetric organic loading (VOL). These factors, which must be considered since the start-up of the system, allow the cultivation of dense biomass, is able to settle quite well at the bottom part of the reactor, even when the reactor suffers of hydraulic shocks (CAMPOS et al., 2003).

The incorporation of an internal gas-liquidseparator (GLS) helps the reactor to work with higher CRT, even when the HRT is quite low.

Considering that the scientific literature does not have any kinetic studies in lab-scale of UASB reactors treating liquid effluents of swine manure with the physicalchemical characteristics described here, the present research aimed at determining the kinetic parameters able to describe the biological conversion process of the substrate by the microorganisms and substrate, and in this approach, subsidy the measurement for scaling-up of pilot and full-scale UASB reactors.

In this research the kinetic biochemistry study used the anaerobic biomass and searched to find out the microorganisms growth and the consuming velocities of the substrate, and also the sub-products formation. These velocities can be expressed mathematically in terms of models which represent an adequate dynamic of this type of process (CAMPOS, 1990).

Many are the aspects which can have influence on the kinetic of the microorganism population. According to many kinetic studies these can be affected by the following parameters (SPERLING, 1996).

- Composition;

- $\mathrm{pH}$;

- $\quad$ Reology and temperature

- Internal controls;

- $\quad$ Adaptability;

- Heterogenic bacterial populations;

The interactions between cellular mass and environment can also be pointed, such as:

- $\quad$ Nutrients transferences;

- $\quad$ Temperatures and products.

It is not possible to try to formulate a kinetic model able to include all aspects and involved details related to the biochemistry reactions, in special those with high complexity. Consequently, many simplifications must be done in order to transform in a useful and applicable model. There is also a great difficulty in describing these kinetic conversions mathematically, due to its substrate complexity and many bacterial population involved. In the other side, the complex mathematical models are not desirable, mainly due to the difficulties to handle them in order to simulate the involved process as a whole.

Two mainly variables constitute the basis of all biological models: ( $\left.1^{\underline{a}}\right)$ substrate concentration; and ( $\left.2^{\underline{a}}\right)$ microorganism concentration. In this work the kinetic was based in the mass balance describing quantitatively the all input and output materials, as well as, the accumulated substances that stay in the physical limit of the system.

The mass balance is based in the Mass Conservation Law, described by Equations (1) and (2).

Ciênc. agrotec., Lavras, v. 29, n. 5, p. 1045-1051, set./out., 2005 


$$
\begin{gathered}
\text { (Inlet-Outlet) } \quad \text { (Production-Consumption) } \\
\frac{d(C V)}{d t}=\left(Q C_{0}-Q C\right)+\left(\mu . X_{r} V_{r}-k_{d} X_{r} V_{r}\right) \\
C \frac{d V}{d t}+V \frac{d C}{d t}=\left(Q C_{0}-Q C\right)+\left(\mu X_{r} V_{r}-k_{d} X_{r} V_{r}\right)
\end{gathered}
$$

In biological reactors the volume is fixed, therefore, its variation rate to the time is zero, as it is shown in the Equation (3)

$$
\begin{gathered}
\frac{d V}{d t}=0 ; \text { where } \\
V \frac{d C}{d t}=\left(Q C_{0}-Q C\right)+\left(\mu . X_{r} V_{r}-k_{d} X_{r} V_{r}\right)
\end{gathered}
$$

The Equation (4) is able to express the cellular retention time $\theta_{c}$ (day), (METCALF \& EDDY, 2003):

$$
\theta_{c}=\frac{V_{r} X_{r}}{\left(Q C_{0}+Q C\right)}
$$

Where: $V r$ - reactor volume, $(\mathrm{L})$;

$X r-$ microorganisms concentration (VST) in the reactor, (mg.L $\left.\mathrm{L}^{-1}\right)$;

$Q$-flowrate, $\left(\right.$ L.day $\left.^{-1}\right)$;

$C_{0}-\mathrm{COD}_{\mathrm{T}}$ affluent concentration, $\left(\mathrm{mg} . \mathrm{L}^{-1}\right)$;

$C$ - $\mathrm{COD}_{\mathrm{T}}$ effluent concentration, $\left(\mathrm{mg}_{\mathrm{L}} \mathrm{L}^{-1}\right)$. $\mathrm{dt}=0$,

Considering the microorganisms mass balance: $\mathrm{dC} /$

$$
\begin{gathered}
V \frac{d C}{d t}=\left(Q C_{0}-Q C\right)+\left(\mu . X_{r} V_{r}-k_{d} X_{r} V_{r}\right) \\
\frac{1}{\theta_{c}}=\mu-k_{d}
\end{gathered}
$$

The following Equation 6 is much utilized in biological wastewater treatments, and is known as Monod kinetic. Its importance resides in its shape which can represent approximately the zero order kinetic, as well as, the first order equation, and also the transition among themselves.

In the beginning of substrate decomposition reaction, when its concentration is yet very high, it has no limitation of its concentration in the midst and the global removal rate is quite similar to the first order kinetics. However, due to the substrate consumption, the reaction rate start to decrease, characterizing a transient region, and can be considered as a variable order, when the substrate concentration is quite low, therefore, the reaction rate is limited by the low substrate concentration available in the midst.

In this situation the kinetic equation shows to be of first order. This both situations happen due to the low $\mathrm{COD}_{\mathrm{T}}$ concentration in the effluent " $\mathrm{C}$ " $\left(\mathrm{mg} . \mathrm{L}^{-1}\right)$, and due to the limit substrate concentration " $K s$ " (mg.L-1 ofCOD).

$$
\mu=\frac{\mu_{\text {máx }} C}{K_{s}+C}
$$

$$
\text { Where: } \mu=\frac{\mu_{\text {máx }}}{2}
$$

The cellular growth $(Y)$, interpreted as the mass of cells formed per mass of substrate consumed can be related to the limiting substrate, as shown in Equation (8).

$$
\frac{d C}{d t}=\frac{\mu_{\text {máx }} C X_{r}}{\left(K_{s}+C\right) Y}
$$

The effect of the endogenous methabolism $k d-$ represents the cells mortality and can be described according to Equation (9):

$$
\frac{d X}{d t}=-k_{d} X
$$

Putting together the Equations 8 and 9, it will be formed the Equation (10) described below:

$$
\frac{d C}{d t}=\frac{\mu_{\text {máx }} C X_{r}}{\left(K_{s}+C\right) Y}-k_{d} X_{r}
$$

\section{MATERIAL AND METHODS}

The experiment was carried out in the Water Analysis Laboratory of the Engineering Department (LAADEG) at the Federal University of Lavras (UFLA), using a system composed with three experimental units: acidification and equalization tank (AET), an anaerobic reactor (UASB) and an aerated facultative pond (AFP). In this research it was analyzed just the parameters related to the UASB reactor, the other units were not studied with this objective. The swine manure used was collected in a herd installed at the Zoo-technical Department at UFLA University. The installations were daily washed, normally during the morning, before feeding procedure. The generated liquid effluent has in its composition fresh 
manure, urine and food which was colleted and canalized until it was united in an unique pipe. From this point the liquid effluent was collected to be used in the experiment. The number of swine during the experimental period was about 500 animals. The system were fed in batch conditions in the AET, and after that, the effluent was pumped to a heat equipment, then to the UASB reactor, only then, in order to be polished, to an Aerobic Facultative Pond (AFP). The volumes of the AET, UASB and AFP were 38; 11.7 and 16 liters, respectively. The system flowchart and the plant sketch representation are shown in the Figures 1 and 2, respectively.

The monitoring of the system was realized through the determination of the physical-chemical parameters collected from the affluent and effluent of each one of the units: AET, UASB and AFP. The following physicalchemical parameters were analyzed: flowrate, temperature, $\mathrm{pH}$, total chemical oxygen demand $\left(\mathrm{COD}_{\mathrm{T}}\right)$; total solids (TS), and total volatile solids (TVS). The samples were analyzed according to the APHA (1998). The determinations of $\mathrm{pH}$, temperature and flowrate were measured daily, while the analysis of $\mathrm{COD}_{\mathrm{T}}$, TS and TVS were analyzed two times per week.

The parameters kept constant after the transient period or during the steady-state phase of the UASB reactor were temperature and the flowrate.

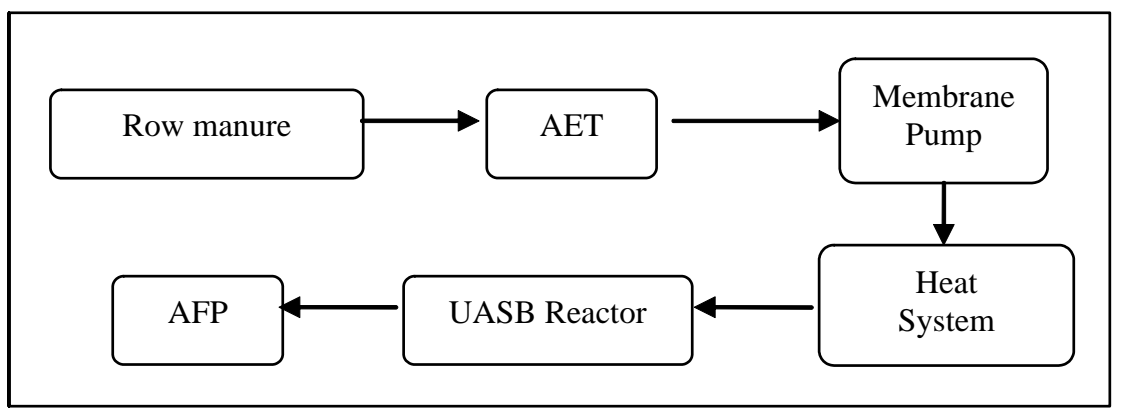

FIGURE 1 - Flowchart of the system.

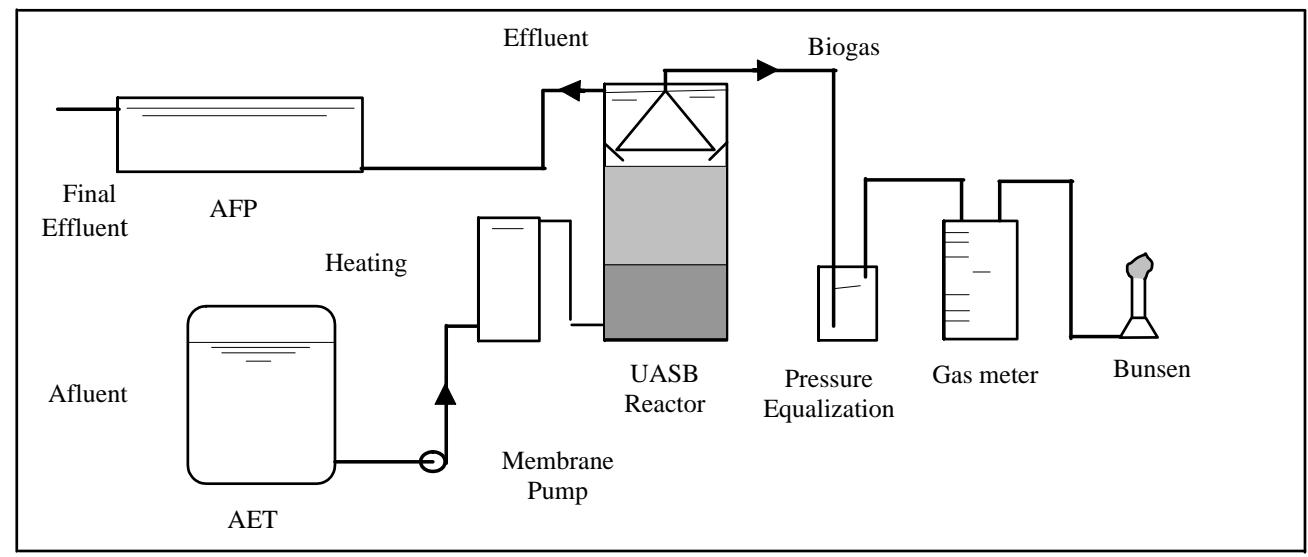

FIGURE 2 - Plant sketch of the system.

Ciênc. agrotec., Lavras, v. 29, n. 5, p. 1045-1051, set./out., 2005 
Concerning the statistic methodology employed to the data, it was applied, in order to exam the existence of linear relation between two variables, the correlation coefficient of the sample " $r$ " (FAOSTAT, 2001; LEVINE et al., 2000). This statistic methodology called test of $t$ is

estimated using the equation $t=\frac{r}{\sqrt{\frac{1-r^{2}}{n-2}}}$, where the $t$ test follows a $t$ distribution, with $\mathrm{n}-2$ degree of freedom; being: $r^{2}=\frac{S Q \operatorname{Re} g}{S T Q}\left(\mathrm{R}_{\text {squared }}\right), r=\sqrt{r^{2}} \quad\left(\mathrm{R}_{\text {multiple }}\right)$ and $n$ equal to the freedom degrees; where the SQReg is equal to the addition of the squares due to the regression, and $S T Q$ is equal to the total addition of squares. For hypothesis test of $\mathrm{H}_{0}: \rho=0$ (does not exist correlation) or $\mathrm{H}_{1}: \rho \neq 0$ (exist correlation).

\section{RESULTSAND DISCUSSION}

The UASB reactor was operated during nearly 250 days without interruption. The average $\mathrm{pH}$ value was 7.7, showing a good buffer condition.

During the same period the environment temperature average was about $22.7^{\circ} \mathrm{C}$, and for the purpose of the reactor works in an average temperature of $25 \pm 2^{\circ} \mathrm{C}$, the heat system operated at an average temperature of $41.2^{\circ} \mathrm{C}$.

The system flow rate was determined based in the hydraulic retention time (HRT) adopted. The minimum flowrate, during the start-up was $0.21 \mathrm{~L} \cdot \mathrm{h}^{-1}$, resulting in a maximum HRT of 55 hours, while the maximum flowrate was $0.71 \mathrm{~L} . \mathrm{h}^{-1}$, resulting a HRT about 16 hours. The flowrate average value was $0.45 \mathrm{~L} \cdot \mathrm{h}^{-1}$.

The variation of the $\mathrm{COD}_{\mathrm{T}}$ values observed was due to the liquid effluent characteristics originated in the pigsty, since it does not have any control on the water management even on the clean products utilized to wash out the confining swine installation. The average value of $\mathrm{COD}_{\mathrm{T}}$ in the affluent of the UASB reactor was about 1,911 mg.L $\mathrm{L}^{-1}$, for all HRT's. The average values of $\mathrm{COD}_{\mathrm{T}}$ in the effluent of UASB reactor for each HRT $(55,39,34,24$ and 16 hours), were: $216 ; 126 ; 213 ; 123 ; 120$ and $406 \mathrm{mg} . \mathrm{L}^{-1}$, respectively.

The average concentrations of TVS in the effluent of the UASB reactor for each HRT $(55,39,34,24$ and 16 hours), were: $249 ; 263 ; 284 ; 203 ; 147$ and $363 \mathrm{mg} . \mathrm{L}^{-1}$, respectively. The average concentrations of TVS of the sludge in the UASB reactor for each HRT $(55,39,34,24$ and 16 hours), determined from each sample port installed along the reactor profile, were: $23.822 ; 21.958 ; 23.077 ; 22.045$; 20.658 and $20.688 \mathrm{mg} . \mathrm{L}^{-1}$, respectively. All this data are presented at Table 1.

Table 1 shows the values of $\mathrm{COD}_{\mathrm{T}}$ affluent and effluent of the UASB reactor, denominated $\mathrm{C}_{0}$ e $\mathrm{C}$, respectively. The average values of TVS (considered as microorganisms) in the reactor (Xw e Xr) and in the effluent $(\mathrm{Xe})$, as well as, the average value of flowrates $(\mathrm{Qw})$ withdrawn from each port, as a function of each HRT. With the values presented in Table 1, it was estimated the Cellular Retention Time "CRT" in days, as well as the other parameters necessary to the development of the kinetic studies.

TABLE 1 - Average values of operational parameters in the UASB reactor.

\begin{tabular}{|c|c|c|c|c|c|c|c|c|}
\hline HRT (h) & Qe $\left(\right.$ L.d $\left.^{-1}\right)$ & $\operatorname{Vr}(\mathrm{L})$ & $\begin{array}{c}\mathbf{Q w} \\
\left(\mathbf{L . d} \mathbf{d}^{-1}\right)\end{array}$ & $\begin{array}{c}\text { Xe } \\
\left(\mathbf{m g} . \mathbf{L}^{-1}\right)\end{array}$ & $\begin{array}{c}\mathbf{X w} \\
\left(\mathbf{m g} \cdot \mathbf{L}^{-1}\right) \\
\end{array}$ & $\begin{array}{c}\mathbf{X r} \\
\left(\mathbf{m g} \cdot \mathbf{L}^{-1}\right)\end{array}$ & $\begin{array}{c}\mathbf{C}_{\mathbf{0}} \\
\left(\mathbf{m g} . \mathbf{L}^{-1}\right)\end{array}$ & $\begin{array}{c}\mathrm{C} \\
\left(\mathbf{m g} \cdot \mathbf{L}^{-1}\right)\end{array}$ \\
\hline 55 & 5.09 & 11.72 & 0.000667 & 249.60 & $23,822.00$ & $23,822.00$ & $1,910.50$ & 216.42 \\
\hline 39 & 7.18 & 11.72 & 0.001250 & 263.71 & $21,958.00$ & $21,958.00$ & $1,910.50$ & 129.71 \\
\hline 34 & 8.21 & 11.72 & 0.001127 & 284.21 & $23,077.25$ & $23,077.25$ & $1,910.50$ & 213.49 \\
\hline 24 & 11.54 & 11.72 & 0.001159 & 203.06 & $22,045.00$ & $22,045.00$ & $1,910.50$ & 123.36 \\
\hline 17 & 16.32 & 11.72 & 0.001429 & 145.40 & $20,658.40$ & $20,658.40$ & $1,910.50$ & 120.58 \\
\hline 16 & 17.50 & 11.72 & 0.001786 & 363.00 & $20,688.92$ & $20,688.92$ & $1,910.50$ & 406.54 \\
\hline
\end{tabular}


Figure 3 shows the pair of coordinates, using the linear regression analysis, through which it could be obtained the coefficient values of biomass growth " $Y$ " (mgCOD.mgTVS ${ }^{-1} \cdot \mathrm{d}^{-1}$ ) and the coefficient of decay (endogenous biomass) " $K_{d}$ " $\left(\mathrm{d}^{-1}\right)$.

Figure 4 shows a pair of coordinates which presents the regression analysis able to demonstrate the equation from which the maximum growth rate " $i_{\max }$ " $\left(\right.$ day $\left.^{-1}\right)$, and the limiting substrate concentration " $K s$ " $\left(\mathrm{mgCOD}^{-1}\right)$ values were determined.

The linear equation shown in Figure 3 is: $y=2.9543 x$ +0.0409 ; with a $\mathrm{R}_{\text {multiple }}=0.64$. The statistical study for determining the correlation was the test of " $t$ ". Since the result found was $\mathrm{t}=1.6664 ; \mathrm{t}_{\mathrm{n}-2}=1.5332$; using the critical values from the table of " $t$ ", with an area of tail superior, with á $=0.10$, it can be concluded that, since $\mathrm{t}=1.6664>\mathrm{t}_{4}$ $=1.5332, \mathrm{H}_{0}$ can be rejected. Once the null hypothesis was rejected, it can be concluded that there is an association between the growth " $Y$ " $\left(\mathrm{mgCOD} \cdot \mathrm{mgTVS}^{-1}\right.$. day $\left.{ }^{-1}\right)$ and the endogenous decay " $K d$ " $\left(\right.$ day $\left.^{-1}\right)$ coefficients, with a significant level of 0.10 .

The linear equation shown in the Figure 4, is: $\mathrm{y}=$ $1,823.5 x+31.749$; with a $\mathrm{R}_{\text {mutiple }}=0.45$. Since the result found $\mathrm{t}=1.00922 ; \mathrm{t}_{\mathrm{n}-2}=0.7407$; with an area of tail superior with a $=0.25$, and since $\mathrm{t}=1.00922>\mathrm{t}_{4}=0.7407, \mathrm{H}_{0}$ can be rejected. Since the null hypothesis was rejected, it can be concluded that there is an association between the maximum growth rate " $i_{\max }$ " $\left(\right.$ day $\left.^{-1}\right)$ and the limiting substrate concentration " $K s$ " (mg.L $\mathrm{L}^{-1}$ de COD) coefficients, with a significant level of 0.25 .

The experimental research demonstrated adequate kinetics parameters within the range presented in the literature (CAMPOS, 1990). The ranges of the kinetic parameter values obtained for the analyzed UASB were: for growth coefficient " $Y$ "; 0.4231e"Ye"0.3046 mgCOD.mg-1. TVS.d ${ }^{-1}$, for the endogenous decay coefficient " $k_{d}$ "; $0.0173 \mathrm{e}$ " $k_{d} \mathrm{e}$ " $0.0125 \mathrm{~d}^{-1}$, for the maximum growth rate $i_{\max }$ "; $0.03938 \mathrm{e} " i_{\max } \mathrm{e}$ " $0.2835 \mathrm{~d}^{-1}$, and for the limiting substrate concentration " $K s$ "; $71.80 \mathrm{e}$ " $K s$ e"51.70 mg.L ${ }^{-1}$ of COD.

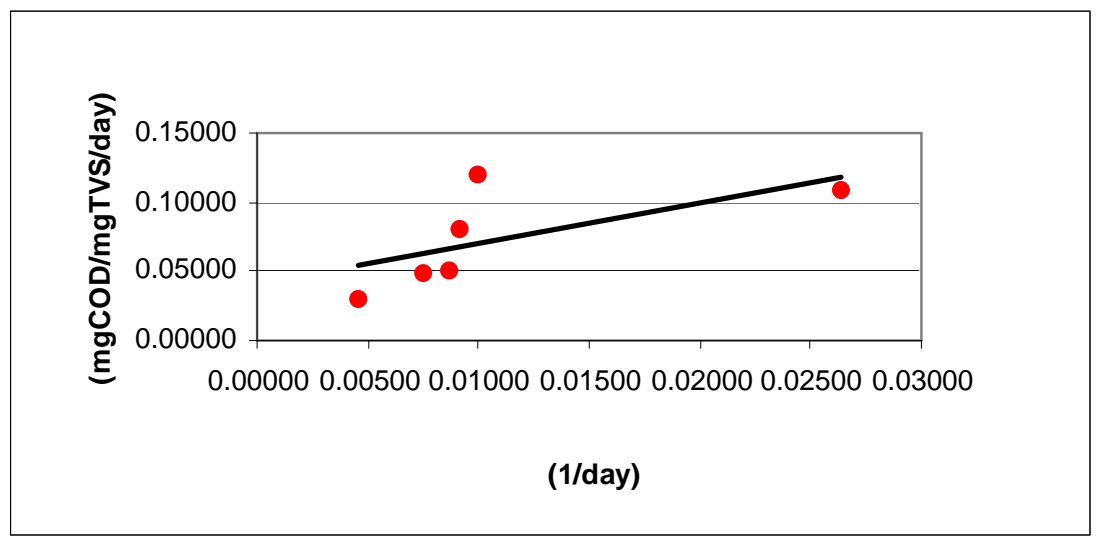

FIGURE $3-Y$ e $K_{d}$ determination in the UASB reactor.

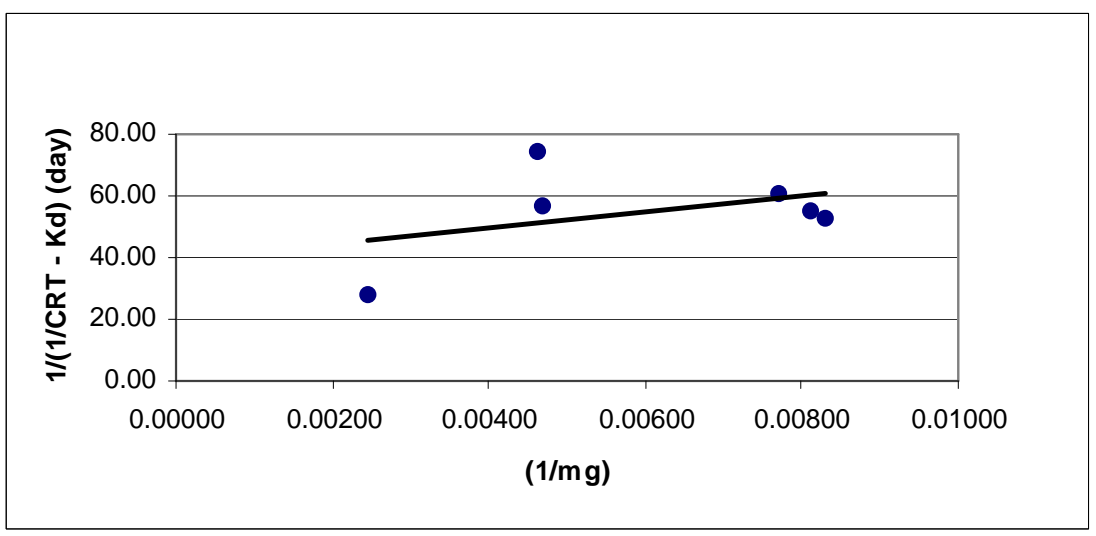

FIGURE 4 - Determination of $\mu_{\max }$ and $K s$ in the UASB reactor.

Ciênc. agrotec., Lavras, v. 29, n. 5, p. 1045-1051, set./out., 2005 


\section{CONCLUSIONS}

The kinetic studies applied to the present research demonstrated very adequate, since the values found were in the range of the literature specified. The statistical methodology applied, also allowed the faithfulness of the kinetic parameters, which could be used even for subsiding simulation studies, as well as to be applied in scaling-up this type of reactor permitting the engineer a greater confidence in designing a pilot or a full scale UASB reactors.

\section{ACKNOWLEDGEMENTS}

The authors would like to acknowledge the Conselho Nacional de Desenvolvimento Científico e Tecnológico - CNPq for the sponsorships given to the Master of Science and graduated students (PIBIC).

This acknowledgement is in addition extended to UFLA, which allowed the authors to use its laboratory (LAADEG) as well other facilities, and also to the enterprise of technological base Global Ciência e Tecnologia-GCT for its support.

\section{BIBLIOGRAPHY}

AMERICAN PUBLIC HEALTH ASSOCIATION. Standard methods for the examination of water and wastewater. 20. ed. New York, 1998. 1134 p.

ASSOCIAÇÃO BRASILEIRA DAS INDÚSTRIAS PRODUTORAS E EXPORTADORAS DE CARNE SUÍNA. Dados da ABIPECS. São Paulo, 2002. Disponível em: <http/ Wwww.abipecs.com.br/histprodução.aps $\lambda$. Acesso em: 20 jul. 2003 .

CAMPOS, C. M. M. Physical aspects affecting granulations in UASB Reactors. 1990. 459 f. Thesis (Ph.D) - Universidade de Newcastle upon Tyne, Newcastle, 1990.

CAMPOS, C. M. M. Reatores anaeróbios de última geração. Lavras: UFLA, 1998.59 p. Apostila.

CAMPOS, C. M. M.; HARDOIM, P. C.; BOTELHO, C. G.; SEVERO, J. C. A. Programa computacional para simulação e dimensionamento de sistemas de tratamento de dejetos suínos. In: CONGRESSO BRASILEIRO DE ENGENHARIA AGRÍCOLA, 28., 1999, Pelotas. Anais... Pelotas: SBEA, 1999. CD-ROM.
CAMPOS, C. M. M.; LUIZ, F. A. R.; FIGUEIREDO, J. G.; SALEH, B. B. Avaliação do desempenho de um sistema anaeróbio em bancada tratando leite diluído simulando efluente de laticínio In: CONGRESSO BRASILEIRO DE ENGENHARIAAGRÍCOLA, 32., 2003, Goiânia. Anais... Goiânia: Novas Fronteiras, 2003.

FAOSTAT. FAO Statistical Databases. 2001. Disponível em: <http://apps.fao.org?. Acesso em: 10 set. 2001.

KATO, M. T. et al. Configurações de reatores anaeróbios. In: CAMPOS, J. R. Tratamento de esgotos sanitários por processo anaeróbio e disposição controlada no solo. Rio de Janeiro: ABES/PROSAB, 1999. cap. 3, p. 53-100, $405 \mathrm{p}$.

LEVINE, D. M.; BERENSON, M. L.; STEPHAN, D. Estatística: teoria e aplicações usando Microsoft ${ }^{\circledR}$ Excel em português. Rio de Janeiro: LTC, 2000. 811 p.

METCALF; EDDY. Wastewater engineering: treatment, disposal, reuse. 4. ed. [S.1.]: Metcalf \& Eddy, 2003. 1819 p.

NG, W. I.; CHIN, K. K. Treatment of piggery wastewater by expanded-bed anaerobic filters. Biological Wastes, Oxford, v. 26, n. 3, p. 215-228, 1988.

OLIVEIRA, P. A. V. de (Coord.). Manual de manejo e utilização dos dejetos de suínos. Concórdia: EMBRAPACNPSA, 1993. 188 p. (Documentos, 27).

OLIVEIRA, R. A. de. Efeito da concentração de sólidos suspensos do afluente no desempenho e características do lodo de reatores anaeróbios de fluxo ascendente com manta de lodo tratando águas residuárias de suinocultura. 1997. 359 f. Tese (Doutorado em Engenharia Civil) - Escola de Engenharia de São Carlos, Universidade de São Paulo, São Carlos, 1997.

SPERLING, M. Princípios básicos do tratamento de esgotos. Belo Horizonte: UFMG, 1996. v. 2, 211 p.

ZHANG, R. H.; DAGUE, R. R. Treatment of swine wastes by the anaerobic sequencing batch reactors system. In: INTERNATIONAL SYMPOSIUM ONAGRICULTURAL AND FOOD PROCESSING WASTES, 7., 1995, Chicago. Proceedings... Chicago: ASAE, 1995. p. 301-308. 